Policy Research Working Paper 2515

Firm-Level Survey Provides Data on Asia's Corporate Crisis and Recovery

Mary Hallward-Driemeier
This rich new database on

4,000 Asian firms-operating in Indonesia, the Republic of Korea, Malaysia, the Philippines, and Thailand-focuses on the impact of Asia's economic crisis and on the longer-run determinants of productivity, employment practices, and financial structure.

The World Bank

Development Research Group Macroeconomics and Growth January 2001 
Polscy Resfarch Working Paper 2515

\section{Summary findings}

Researchers have decried the limited supply of objective, comparable firm-level data from developing countries. Hallward-Driemeier describes a new database that helps fill this information gap.

The database has detailed records on 4,000 firms operating in Indonesia, the Republic of Korea, Malaysia, the Philippines, and Thailand. A comparable survey instrument and sampling methodology was used in each country, and all five studies were carried out simultaneously. The data cover three years (1996-98), allowing for measurements of firm performance before and immediately after the East Asian financial crisis.
The questionnaire focused on measuring the impact of the regional financial crisis at the microeconomic level and understanding the longer-run determinants of productivity, employment practices, and financial structure.

This database-the first step in the important Firm Analysis and Competitiveness Surveys initiative that the World Bank is spearheading - will be joined by additional country databases. The aim is to fill the gap in much-needed microeconomic evidence using comparable instruments.

This paper-a product of Macroeconomics and Growth, Development Research Group-is part of a larger effort in the group to collect comparable firm-level information from developing countries. The research was funded by the Bank's Research Support Budget under the research project "Impact of the East Asian Crisis" (RPO 632-28). Copies of this paper are available free from the World Bank, $1818 \mathrm{H}$ Street NW, Washington, DC 20433. Please contact Emily Khine, room MC3-341, telephone 202-473-7471, fax 202-522-3518, email address kkhine@worldbank.org. Policy Research Working Papers are also posted on the Web at www.worldbank.org/research/workingpapers. The author may be contacted at mhallward $a$ worldbank.org. January 2001. (33 pages)

The Policy Research Working Paper Series disseminates the findings of work in progress to encourage the exchange of ideas about development issues. An objective of the series is to get the findings out quickly, even if the presentations are less than fully polished. The papers carry the names of the authors and should be cited accordingly. The findings, interpretations, and conclusions expressed in this paper are entirely those of the authors. They do not necessarily represent the view of the World Bank, its Executive Directors, or the countries they represent. 


\title{
Firm-Level Survey Provides Data on Asia's Corporate Crisis and Recovery
}

\author{
Mary Hallward-Driemeier \\ DECRG $^{*}$
}

\footnotetext{
* I am extremely grateful to Francis Colaco, David Dollar, Dominique Dwor-Frecaut, Kyle Peters and Ken Sokoloff whose support and guidance were instrumental to the survey initiative and to Giuseppe Iarossi, Stacy Nemerof, Dee Sutthiphisal, Dennis Tao, and Hairong Yu for their tremendous assistance in organizing the dataset. The cooperation and participation of National Development Planning Agency (BAPPENAS) and Bada Pusat Statistik in Indonesia, Korea Institute for Industrial Economics and Trade (KIET) in Korea, the Economic Planning Unit in the Prime Minister's Office in Malaysia, the National Statistics Office and the National Economic and Development Authority in the Philippines and the Ministry of Industry in Thailand are gratefully acknowledged. Financial support was received by the Policy and Human Resource Development Fund (Japan) and the Asia-Europe Meeting (ASEM) Trust Fund.
} 



\title{
Firm-Level Survey Provides Data on Asia's Corporate Crisis and Recovery
}

\author{
Mary Hallward-Driemeier \\ DECRG
}

A new database of 4000 firms in 5 East Asian countries ${ }^{1}$ provides insights into the private sector at a critical time in the region's development. There has been an extensive debate on the degree of technological improvement and factor accumulation in the region and what characteristics best predict productivity growth ${ }^{2}$. With the recent financial crisis, concerns of credit constraints and the extent of unemployment has gained widespread public attention. ${ }^{3}$ Until now, these questions have been examined using aggregate data or through case studies. The new database makes available extensive firm level information that can address these questions and other pressing issues of the determinants of competitiveness and firm reactions to the crisis.

The database provides information for the same firms over a three year period, covering 1996 to 1998 . Designed to analyze a broad ranges of issues, both within and across the participating countries, it contains information on such topics as productivity, firm structure, financial position, employment practices, investment and technology acquisition. The data was collected using similar survey instruments and sampling methodologies so that cross country comparisons can be made directly.

Many existing firm-level databases are restricted to a single country, ask mostly subjective questions or are limited to a particular type of firm or aspect of a firm's behavior. (For an overview of existing surveys see Recanatini, Wallsten and Xu 2000). This database is a contribution as it provides a wide set of comparable and objective measures for a large sample of firms in 5 countries. Building on the example of the Regional Program on Enterprise Development (RPED) overseen by the World Bank that sampled 150-200 firms in 5 African countries between 1993-95, this database greatly increases the sample size and is the first to be made publicly available. It is the hope that more such comparable firm-level datasets will be made public in the near future as part of the World Bank's Firm Analysis and Competitiveness Surveys (FACS) initiative.

\section{Comparison with other firm-level databases}

Basic firm-level production and employment data is collected in most countries. However, it is only made available to the public in aggregate form, with rare exceptions. This greatly limits the type of research for which it can be used. The most common firmlevel data that is publicly available covers publicly traded firms. These firms are required to disclose certain types of information as a condition of being listed on the exchange. Companies such as Worldscope and Extel have made businesses out of gathering this information from company reports, compiling it and selling it to reserachers and analysts.

\footnotetext{
${ }^{1}$ While Malaysia conducted the survey and participated in the regional conference to discuss the results and policy implications of the findings, the government officials chose not to make the raw data available for the regional database at this time. Aggregate statistics, however, are presented here for comparison and additional ones are available on the database website.

${ }^{2}$ See Young 1995, Young 1996, Krugman 1996, Hseih 1997, Rodrik 1998.

${ }^{3}$ See Ghosh 1998, Ferri and Domac 1998, Ito and Pereira Da Silva 1998, Sachs 1997.
} 
Researchers have long taken advantage of this information to study firm behavior in various OECD countries. This source of information has also recently been exploited for a broader set of countries in East Asia. Claessens, Djankov, and Lang $(1998,1999)$ examine the publicly listed companies in East Asia to analyze the importance of ownership structures and links to banks in the financial position of firms. However, there are two shortcomings of this data, particularly in the context of developing countries. First, there are only a limited number of variables available. Thus, it is not possible to derive calculations on productivity, worker turnover or export behavior. Second, the sample of firms is hardly representative of the broader population of firms in these countries. In the Southeast Asian countries, non-financial sector listed firms only number 146 in the Philippines, 258 in Korea, 264 in Indonesia, 636 in Malaysia and 427 in Thailand. Understanding the performance and financial practices of the largest firms in a country is certainly important, but a broader set of firms is needed to shed light on the economy as a whole.

In recent years there has been increased attention paid to qualitative surveys of countries' business environment such as those conducted by Transparency International, the World Economic Forum and the World Bank Business Environment Survey. While based on the responses of individuals, the measures are not tied to firm-specific performance. Available in aggregated form, they seek to capture features of the national economy. The measures are based on interviews with CEOs who report their impressions of the severity of various potential bottlenecks to doing business in a country. Thus these datasets provide purely subjective measures. A prime concern of using this data is how to interpret comparisons made across countries. There can be cultural differences in the degree to which respondents will complain about issues, and there are differences in expectations against which actual conditions are measured. For example, if there is no tradition of using the judicial system to resolve contract disputes, it is not necessarily going to be ranked as low as in a country where people do expect fairer judicial practices, but are frustrated by weaknesses or corruption in the system. (Pfeffermann 2000)

There are a number of datasets available that are more limited in scope. They focus on a particular sector within a country or have information on a particular aspect of firm behavior, such as training ${ }^{4}$, production and productivity ${ }^{5}$, tax payments ${ }^{6}$ or trade practices $^{7}$. These databases point to the importance of having quality micro-data available. Almost all such studies conclude that greater data collection efforts would be extremely valuable (See Tybout 1998). This database is one step towards filling this information gap.

This database thus makes a contribution on several dimensions. First, the survey contains objective, quantitative measures of firm performance. While it does include some qualitative measures, attempts were made to ask complementary questions that give

${ }^{4}$ Batra and Tan (1997) for Colombia, Mexico and Taiwan (China)

5 Aw and Hwang (1995) for Taiwan (China); Corbo and deMelo (1986) for Chile; Cortes et.al (1987) for Colombia; Bhavani (1991), Hill and Kalirajan (1993), Little et.al. (1987), Page (1984) and Ramaswamy (1994) for India; Page (1980) for Ghana; Tyler (1979) for Brazil; Kalirijan and Tse (1989) for Malaysia; Pitt and Lee (1981) for Indonesia. Biggs et al. (1995) and Bigsten et. al. (1999) are some of the few cross country studies available, using the comparable data from the RPED study in Africa.

${ }^{6}$ Gauthier and Gersovitz (1997) .

${ }^{7}$ Kraay (1998), Aitken, Hanson and Harrison (1994). 
an objective measure of the issue. For example, managers were asked how much of a problem red tape and bureaucracy are, and they are also asked the number of days it takes to clear goods through customs. Also, production, employment, investment and balance sheet data give quantitative measures of firm performance that can be directly used for meaningful comparisons.

The surveys use comparable methodologies and survey instruments in all five countries. While particular questions were modified to reflect institutional differences, the databases can easily be linked together. This greatly reduces difficulties associated with combining data on different countries.

The database features large, randomly selected samples with good coverage of subgroups of firms. Each country sampled between $650-950$ firms, for a total of over 4000 firms. Thus, there are adequate numbers of firms to analyze sub-groups based on sector, size, export practices etc. Also, the samples were drawn randomly rather than focusing on the best performers or only listed companies. Thus, the results are applicable to the wider population of manufacturing firms in the economy, making it easier to determine policy implications and recommendations.

The data covers three years, creating a panel rather than a simple cross-section of firms. This gives the opportunity to look at changes over time. In particular, it allows for measures of the impact of the crisis. For econometric studies, it also allows for firm heterogeneity to be controlled for and provides greater opportunities to use lagged variables as instruments in cases where the endogeneity of an explanatory variable could be of concern.

Finally, there is comprehensive coverage of firm behavior in the database. The survey not only collects information on production, it has extensive data on financial characteristics of the firm, its employment practices, corporate governance information, methods of acquiring technology, and responses to the crisis. The rich set of variables allows different characteristics to be linked in analyzing research questions.

This paper describes the database, discussing the variables that are included, the methodology used in collecting the data and outlines some of the results coming from initial studies. It also raises avenues of research that could be examined using the database.

\section{Motivation for the Survey:}

The survey was undertaken to fill an important information gap in the participating countries. Thailand initiated the project. Beyond gathering basic production and employment numbers, there was little information available to policy makers about the private sector. With years of high growth, this had not seemed to be a constraint. However, by 1996, Thai exports were falling after years of spectacular growth. There was a growing appreciation for the need to better understand the determinants of competitiveness and technology transfer. Thailand fielded a first industrial survey in the fall of 1997, with technical assistance provided by the World Bank. Other countries in the region were interested to benchmark themselves and soon the survey took on a regional dimension. With the onset of the crisis, policy makers had an even greater impetus to learn more about their industrial sectors and the challenges 
facing enterprises as they tried to weather the rise in interest rates, depreciation and regional recession.

From the researchers' perspective, the collection of this data provides a new opportunity to learn about firm behavior on a broad set of dimensions and in a manner that is consistent across countries. Much progress has been made on this front for households, with the Living Standards Measurement Studies (LSMS) project now covering 22 countries. There has historically been a paucity of comparable firm-level data, particularly in developing countries. The World Bank is responding to this challenge with its FACS initiative. This cross-country firm-level dataset represents the first of several such data collection efforts. The aim is to use a standardized questionnaire across countries to systematically collect data of interest to policy makers and researchers. Currently, there are FACS projects underway in India, Morocco and Bolivia. A number of additional countries are interested and likely to participate in the project in the near future.

\section{Description of the Data:}

The data covers five of the principal countries in East and Southeast Asia that were hit by the financial crisis in 1997: Indonesia, Korea, Malaysia, the Philippines and Thailand. In each country, 650-950 firms were interviewed for the database, for a total of 4003 establishments. The survey was conducted independently in each country, but a comparable instrument and methodology was used in each. This allows for meaningful comparisons to be made across countries. The overlapping sectoral coverage allows for benchmarking and sector-specific studies also to be conducted.

The information was gathered using a two-pronged approach. Enumerators visited each firm and conducted hour-long interviews with the owner or top manager of the establishment. This more qualitative information covered topics ranging from the ownership structure of the firm, responses to the crisis, technology acquisition, views on the business environment, and relationships with banks and other financial institutions.

A second part of the questionnaire asked for quantitative information. There were three principal sections: production information, financial accounts and human resource questions. This part of the questionnaire was mailed to the plants a couple of weeks prior to the interview. It asks for more specific numbers that would be included in records but that would not necessarily be recalled in an interview setting. It was designed to be completed by the accountant and personnel manager. The enumerators discussed it with the appropriate finance and/or personnel manager during the visit to the firm. Inconsistencies or incomplete answers could then be addressed directly. If necessary, follow-up interviews were conducted to ensure this second part was completed.

It should be noted that the response rates for these sections are somewhat lower than the first part of the questionnaire. Sometimes this was due to a failure of the plant to keep such records. Occasionally there was a refusal to disclose the figures due to concerns that too much information would be divulged - this was particularly true for the balance sheet information. When there was less than full participation, the enumerators and their supervisors would try repeated contacts, often eliciting the help of trade association members too. 
The interviews were all conducted in parallel in the participating countries, so the time-reference is the same. The questionnaires were finalized in mid-1998 and surveys were launched in October and November 1998 and were finished by early March 1999. The timing of the surveys, a year and a half after the onset of the crisis, means adequate time has passed to examine the real impact of the crisis and the steps firms had made in response.

In addition to gathering current data, the questionnaire asked for retrospective data on production, finances and labor. Retrospective data was limited to quantitative questions that would rely on objective records, minimizing some of the weaknesses associated with using such types of questions. Having past records increases the scope for measuring the impact of the crisis, allows for the study of pre-crisis behavior and for the analysis of some (limited) trends.

A number of criteria were used to focus the scope of the survey. The participating governments were particularly interested in issues surrounding the competitiveness of their manufacturing sectors. Rather than be comprehensive of the entire manufacturing sector of the economy, a large sampling was taken of key industries. Thus, the five-seven largest contributors to GDP or trade were targeted in the study. As the products are largely tradable goods (whether or not they are actually traded) they should be good test. cases for how competitive the firms are.

\section{Sampling}

The sample frames were designed in collaboration with the national statistical agencies of the participating governments, with technical assistance from the World Bank. The most recent registry of manufacturing establishments was taken as the population of plants from which the samples were drawn. The specifics for each country are listed below:

Indonesia: The sample was drawn from The Directory of Large and Medium Manufacturing Establishments (defined as having 20 or more employees) that is overseen by BPS (the national statistical office). It contains the population of registered manufacturing establishments based on the national industrial census.

Korea: The Ministry of Industry provided the sample of firms from its database of registered enterprises. The enumeration was carried out by N.I.C.E. under the supervision of the Korean Institute for Industrial Economics and Trade (KIET).

Malaysia: The National Statistics Office provided the population of registered firms. The actual enumeration was carried out by A.C.Nielsen, under the supervision of the Economic Planning Unit of the Prime Minister's Office.

Philippines: The sample was drawn from The List of Establishments, 3800 manufacturing establishments compiled and updated by the National Statistical Office and used as the basis for their industrial statistics surveys.

Thailand: The sample was drawn from the Ministry of Industry's Factory Registration Database, comprised of 122,000 plants.

Within the populations of manufacturing enterprises, key sectors were targeted for the survey. The decision to focus on particular sectors rather than the entire spectrum of: 
manufacturing enterprises stemmed from the desire to have adequate responses in particular industries so as to do sector-specific analysis. To ensure adequate responses by sector, each country chose 5 to 7 sectors, based on their importance in GDP or export sales. Preference was also given to sectors being covered by other participating countries.

\begin{tabular}{|l|c|c|c|c|c|c|c|}
\hline & Autoparts & Chemicals & Electronics & $\begin{array}{c}\text { Food } \\
\text { Processing }\end{array}$ & Garments & Machinery & Textiles \\
\hline Indonesia & & $\mathrm{X}$ & $\mathrm{X}$ & $\mathrm{X}$ & $\mathrm{X}$ & & $\mathrm{X}$ \\
\hline Korea & $\mathrm{X}$ & $\mathrm{X}$ & $\mathrm{X}$ & & & $\mathrm{X}$ & $\mathrm{X}$ \\
\hline Malaysia & $\mathrm{X}$ & $\mathrm{X}$ & $\mathrm{X}$ & $\mathrm{X}$ & $\mathrm{X}$ & $\mathrm{X}$ & $\mathrm{X}$ \\
\hline Philippines & & $\mathrm{X}$ & $\mathrm{X}$ & $\mathrm{X}$ & $\mathrm{X}$ & & $\mathrm{X}$ \\
\hline Thailand & $\mathrm{X}$ & & $\mathrm{X}$ & $\mathrm{X}$ & $\mathrm{X}$ & & $\mathrm{X}$ \\
\hline
\end{tabular}

Once the sectors were selected, the populations were reduced to only include those firms registered as having 20 or more employees. As the challenges facing microenterprises can be quite different, the sample was limited to small, medium and large firms. Twenty employees was chosen as the cutoff as it was a natural breaking point in the classification of firms in all the countries except Malaysia. ${ }^{8}$ At the time of the actual interview, some of the enterprises were employing fewer than 20 employees, so the database does include some smaller firms.

From the pool of firms with 20 or more employees in the chosen sectors, establishments were drawn randomly. The priority was to have a representative sample so that the conclusions could be applied more broadly than if only the top performers were surveyed. Sample weights are available upon request.

\section{Caveats}

A number of caveats should be kept in mind when interpreting the data. The first is that there is survivorship bias. Unavoidably, only those firms that were still in business at the time of the survey could be included. Thus those firms that would have been most vulnerable at the outbreak of the crisis would not be represented in the group of respondents. This should be kept in mind, particularly in analyzing the effects of the crisis. Attempts were made to gauge the extent to which this could be a problem. The population frame drew on 1996 registrations of firms and so the number of nonrespondents due to bankruptcy could be reported. The rates were $10-15 \%$, with the number highest in Indonesia. In the Thai case there is the possibility of looking at the firms that went out of business directly as it was the country that had already run a survey the previous year. About ten percent of firms that were in operation in the fall of 1997 were no longer so in the fall of 1998. This is higher than the normal rate of attrition, but does not indicate that the survivorship bias is too drastic.

\footnotetext{
${ }^{8}$ The Malaysian sample frame differs somewhat as it built on the sample of firms used in a prior survey conducted by the Economic Planning Unit two years prior to this survey. Interested to build a panel, those firms in the selected sectors were included, regardless of the number of employees. Thus, Malaysia has a higher incidence of very small firms.
} 
A second caveat is that there is variation in the response rates of different questions. This is particularly true of the financial data. The response rates vary across country, but they are particularly low in Indonesia. The phenomenon stems from the fact that this was sensitive data, and, for many of the smaller companies, there were asked for information that they do not normally keep. As participation was voluntary, the firms could not be compelled to respond.

A further caveat for the financial data is that there are not standard accounting rules in place in the countries surveyed. While the terms used were carefully explained, there is also no guarantee that the definitions used are comparable across all firms, even within the same country. The enumerators did their best to ensure a consistent set of definitions were used, but researchers are cautioned that the financial data should be closely examined before drawing conclusions.

Lastly, there was only minimal outside verification of the numbers reported on the surveys. The enumerators did ask if there were clear inconsistencies and clarified responses accordingly. However, there were not many sources available to verify the data, particularly as the survey asked for several figures that are not otherwise collected. In some instances it was possible to link our survey with the national statistical databases. However, there is no way to ensure that the numbers reported to the government and to the survey enumerators, even if consistent, are in fact accurate.

Prior to the launching of the survey, there had been a concern that respondents would not be too precise in their answers. In fact, the reverse was true. Many respondents were so keen to provide exact answers that the calculation of the requested figures was a daunting task. In such cases enumerators were told to encourage the managers to provide their best estimate, but that accuracy to the decimal point was not necessary. This was particularly important to ensure that sections in the second part of the questionnaire were not left blank.

\section{Questionnaire}

The questionnaire is extensive, covering many aspects of firm behavior. Due to the large number of variables, it is not possible to describe each in great detail. Rather, each of the 9 principal sections is discussed, highlighting those variables that are not generally available in other sources. Brief descriptions summarizing the data should give researchers a flavor of the type of hypotheses that can be examined. Sections 1-6 were asked during the interview with the manager or owner of the establishment. Sections $7-9$ were completed by the accountant and personnel manager.

\section{General information about the firm}

Before focusing on the particular plant being surveyed, background information is gathered on the firm it is a part of. For the $76 \%$ percent of respondents that are singleplant firms, there is no distinction between the firm and the plant. For multi-plant firms, each plant is not included in the survey. The units of selection were plants not firms, so it is a random event if multiple plants in the same firm were surveyed.

This section focuses on three principal issues: the legal organization of the firm, the ownership structure of the firm, and the previous experience of the founder of the company. The information can be used for measures of the size and age of the firm, the 
concentration of ownership, the extent of foreign ownership and the background of the principal entrepreneur. Table 1 shows the breakdown of foreign versus domestic ownership of firms. Sixteen to $35 \%$ of firms have a foreign partner with a $10 \%$ ownership stake, the rates being lowest in Indonesia and Korea and highest in the Philippines. Within the sample, $30 \%$ are single proprietorships or partnerships, $20 \%$ are listed firms, $40 \%$ are private companies and $10 \%$ are cooperatives or have another form of legal organization. On average, about a fifth of the principal enterpreneurs had had prior experience in the industry, and just over a quarter of them had worked for a multinational corporation or joint venture.

\section{General information about the plant}

The section gathers information on the type of products the plant produces, its primary markets, the government incentive programs the plant participates in, and its principal sources of finance and credit arrangements. The characteristics of the firms in the sample are shown in Table 1. Firms are categorized by size, export status, foreign ownership and sector. Firms are defined here as 'small' if they have less that 150 employees. About $60 \%$ of firms are small according to this definition. Exporters slightly outnumber non-exporters, although there is significant variation across sectors and sizes of firms. Together with the information in section 1 , this provides many of the standard controls used in firm level studies.

\section{Impact of the regional crisis}

The survey contains information of the impact of the crisis on three principal areas: production, finances and employment.

i) Production: The database contains information about changes in capacity utilization, domestic and export sales, and the channels through which the crisis was felt. The detrimental impact was widespread, with over $70 \%$ of firms reporting declines in capacity utilization. ${ }^{9}$

Table 2 profiles the firms that were recovering or expanding in 1998 relative to their performance in 1996 . This is only a small share of the firms, about $13 \%$. There are large sectoral differences across these firms, with only $2 \%$ of these firms in the autoparts sector and $36 \%$ in textiles and garments. This is consistent with the degree of outward orientation of these sectors and that $70 \%$ of the expanding firms were exporters.

Despite the initial hopes for an export-led recovery, the data clearly shows that while exporting firms were relatively better off (non-exporters declines were on average almost $10 \%$ greater), still over a third of exporting firms reported declines in performance of $10-25 \%$. With a significant share of exports sold to neighboring countries, the regional recession has impacted the demand for exports. Coupled with falling dollar prices in many sectors, it is not surprising that the exporting firms have not all experienced the devaluation as sufficient to boost their sales.

The survey results shed some light on the reason for the lack of export-led recovery. Exporters in Korea, Malaysia and Thailand were asked for the reasons for the

\footnotetext{
${ }^{9}$ One interesting result is that the fall in capacity is not just associated with the crisis. Particularly noticeable in Thailand is that capacity utilization was already falling prior to the devaluation in July 1997.
} 
decline in export. The most important reason given was the lack of foreign demand and the lack of stability of foreign markets. The collapse of domestic demand in the five countries and the recession in Japan also hurt exporters, because of the importance of intra-regional trade. Including Japan, about half of the exports of the five countries go to the region (the exception is the Philippines that sells a greater share of its exports to the US). (See Waiquamdee, Drairiksh, and Phongsanarakul (2000)).

ii) Finances: The second subsection gathers information on the financial position of the plant. It asks about liquidity, working capital and availability of credit. It asks also for an evaluation of the factors affecting credit availability. Table 3 shows the results for firms reporting difficulties with inadequate liquidity and the ranking of the factors they perceived to be the source of the problem. Thai and Korean firms were most likely to complain about inadequate liquidity, with decreased revenue and higher input costs as the prime areas of concern. Financial dimensions, in terms of existing debt burden and access to external capital, ranked lower. This finding is consistent with over $70 \%$ of firms reporting lower capacity utilization, while $20 \%$ report having sought and been denied additional external credit. Credit constraints captured the headlines, but the decline in domestic demand was a first order problem for more of the manufacturing sector.

iii) Employment: The last area of focus in this section is how the crisis affected the employment practices of the plant. The database has information on the extent to which plants changed the size of their workforce, the profile of workers who were no longer working at the plant and alternative measures to layoffs that the firm was pursuing.

Almost half the firms in the survey were employing fewer workers in 1998 than they had been prior to the crisis. The rate is highest in Korea, where $60 \%$ have fewer workers. Korea and Thailand are also the countries where the proportion of redundancies are greatest, with over a quarter of firms reporting a decline in employment of over $25 \%$. In Korea, the reduction in total employment was close to $20 \%$. Malaysia is the country where the impact on employment has been mildest. Across sectors, autoparts experienced the largest reductions with $73 \%$ of the firms reducing their workforces, followed by electronics and machinery.

Younger workers were disproportionately made redundant in all countries but Korea. Most of the lost jobs had formerly been held by 21-30 year old workers. Likewise the job losses were concentrated in the production jobs rather than managerial or technical staff. Production jobs represent close to two-thirds of the jobs, but represent three-quarters of the lost jobs. This is most striking in Malaysia and Thailand. The average tenure of those made redundant was 1 to 3 three years. The implication of these patterns is that younger workers with less firm-specific human capital have been those that are let go.

The one exception to this pattern is Korea. In Korea, almost half of the lost jobs had been held by workers in their 30s. Korean firms also had a lower share of production jobs being shed, consistent with the lower overall share of production jobs in Korea, but this category still bore a disproportionate share of the lost jobs. Along with the Philippines, Korean firms also had a higher share of workers with 6 to 10 years tenure 
being let go. This could represent a significant loss of human capital. On the other hand, bearing in mind the loosening of inflexible labor markets, this is consistent with Korean firms using the opportunity to substantially restructure their workforces. This explanation is consistent with the fact that Korean firms are also the most likely to be filling vacancies; a sign that they are reacting to meet their changes in labor demand.

One striking finding is that employment changes are only loosely correlated with changes in capacity utilization; there is evidence of labor hoarding in Indonesia, Thailand and Malaysia. Thus, while the data indicates Korea has made the most progress in adjusting its labor force to the new market conditions, significant labor reductions could still be on the horizon. (see Meng and Duncan (2000))

Research Questions:

- Are SME's credit constrained?

- Does a firm's inability to raise capital affect their production decisions?

- Is there evidence of labor hoarding?

\section{Business environment and infrastructure}

This section asked managers to rate various business environment factors. The focus is not simply on the current state of affairs due to the crisis. Rather, managers were also asked to take a longer run perspective. The questions allow the perceived chief obstacles to growth to be identified and ranked. In addition, countries included questions on the effectiveness of various government programs. The programs listed included both short run crisis measures as well as pre-existing incentive programs.

This section includes both qualitative questions and quantitative measure of bottlenecks. For the qualitative measures, managers were asked to rank various dimensions of the business environment on a scale of 1 to 5. These measures are most useful for intra-country comparisons and to rank the order of bottlenecks. ${ }^{10}$ There is considerable variation among the each of the factors' scores, demonstrating that respondents did differentiate between the severity of different types of potential bottlenecks. Several macroeconomic variables receive high scores, i.e. the decline in demand and high interest rates, that reflect the severity of the crisis at the time of the survey. However, several structural issues are flagged, particularly for non-exporters and foreign firms. These firms find red-tape and corruption to be severe bottlenecks, as is the supply of technical workers. Local firms and non-exporters found access to finance to be a greater obstacle. These qualitative measures are complemented by quantitative measures of bottlenecks. Thus firms are asked about the degree of red tape as well as the number of days it takes to get a shipment through customs (see Figure 1), and they are asked about the quality of infrastructure as well as whether they have their own generator.

Research Questions:

\footnotetext{
10 There are differences in mean scores across countries in the level of complaints made by the respondents. This could be due to cultural differences or differences in expectations for what is seen as acceptable business conditions.
} 
- How do government assistance programs improve productivity, labor practices, and/or investment decisions?

- What types of bottlenecks do exporters find most constraining?

- How do government policies affect firm location?

\section{Technology and product/process development}

The section asks about the R\&D practices of the plant and its sources of technology acquisition. Managers report whether they conduct R\&D and if so, what share of sales it represents. They also provide their sources of new technology, differentiated between domestic and foreign sources. About a quarter of firms acquire their technology from foreign sources; over a third of exporters versus one in six domestically oriented firms. The most common sources are licensing, transfers from partner/parent companies or through the hiring of technical experts.

This section also provides various measures of technology sophistication. It provides measures of the degree of automation of production, the means of verifying the accuracy of outputs, and the vintage of a firm's capital stock (see Figure 2). The differences between exporters and non-exporters is striking. Other than in Korea, where all firms have large shares of new equipment, exporters use significantly more recent forms of equipment.

The survey also includes questions on the relationship with other firms such as subcontractors - both whether they do subcontracting and if they use subcontractors. This information is useful to examine one of the possible channels of technology diffusion. Aggregate data cannot answer the question of how technology is diffused. Information on the sources of technology, its upstream and downstream linkages and measures of productivity allow for this important issue to be examined. (See Blomstrom and Kokko 1997, Aitken and Harrison (1996) and Haddad and Harrison (1993)). The section also provides information on the number of days between when an order is received and the product is delivered.

\section{Research Questions:}

- What determines firms' decisions to adopt new technologies?

- Does (foreign) ownership affect the extent of technology diffusion?

- Do sub-contracting relationships foster greater technology diffusion?

\section{General financial practices}

This section asks questions about the number and type of financial institutions the plant does business with. It asks about the sources of finance a firm uses and whether its statements are reviewed by external auditors. It also asks about the role of its board of directors and how major decisions are made.

In section three when firms gave feedback on the impact of the crisis on their financial position, declines in cash flow were highlighted over declines in access to credit. Examining the sources of working capital and the reliance on internal funds demonstrates why this pattern is reasonable, particularly for the SMEs and non-listed enterprises. Only about 25 (Indonesia and Malaysia) to 40 percent (Thailand) of working 
capital requirements of surveyed firms come from loans, the bulk (between 50 and 65 percent) of working capital requirements come from retained earnings, see Figure 3. Also Thai and Indonesian firms get about one third and Korean, Malaysian, and Filipino firms about 15 percent of their working capital from informal sources of financingfamily, partners, informal money lenders. Thus Thailand, the country with the highest reliance on loans to finance working capital, is also the country where firms complained the most about the lack of loans for working capital. Given this high reliance on internal funds for working capital, it is less surprising that firms report liquidity concerns from reduced sales over credit availability as the principal cause for output declines.

A central issue of corporate governance is the relationship between the firm and its financial institution(s). The disclosure and transparency of information is of particular interest. Firms were asked if they were required to provide audited statements to receive a loan. Of those with $20 \%$ or more of their financing provided by bank or financial company loans, the share that are so required ranged from $40 \%$ in Indonesia and Thailand to $70 \%$ in Korea, Malaysia and the Philippines. If firms are only interested in securing a letter of credit for trade finance, the issue of transparency is not so important. But to the extent that many firms' only source of finance is short-term trade credit that they in fact use to finance investment or other longer run activities, the issue is still pressing. For the SMEs, the concern of the lack of transparency is mitigated somewhat by the fact that over half the SMEs have maintained a relationship with the same financial institution over the entire life of the enterprise. Even if there is no objective reporting of financial information in these cases, the financial institution will have built up knowledge about their client.

\section{Research Questions:}

- Does management entrenchment (tenure, equity, and familial ties) affect corporate decisions?

- How do ownership links affect leverage decisions?

\section{Production and investment}

The data in this section provides the basis for productivity analysis. It reports information on production, sales, purchases of inputs, energy, changes in inventory, and investment. It also gathers information on the destination markets for exports. With this information, value added can easily be computed. The information on capital and labor are available too so production functions can best estimated. These measures of productivity can be compared with those available in the technology sections. There is a growing literature on productivity studies in East Asia. (Young (1995), Hsieh (1999)) Much of the analysis has used industry level data. With microdata now available, this dataset provides the opportunity to make a substantial contribution to this debate (See Hallward-Driemeier, Iarossi, and Sokoloff (2000)).

Table 5 reports the capital intensities of firms across sectors and countries. Korea is clearly the most capital intensive country, followed by Malaysia, then Thailand and the Philippines and finally by Indonesia. This is consistent with the differences in the vintage of capital reported in section 5 and Figure 2 . Country differences are also reflected in the investment behavior of firms. However, important differences in the export orientation and size of firms emerge. There is a steady overall rate of firms that 
invest every year (about two-thirds), with rates highest in Korea and lowest in Indonesia. With the onset of the crisis, the number of firms in each country that invest does not change dramatically. Rather, the adjustment comes in the size of the investment, with the large majority making smaller investments relative to their capital stocks. There is also evidence of the lumpy nature of investments; small firms are less likely than large firms to invest every year, but when they do, their investment is larger relative to their capital stock. In contrast, larger firms have greater opportunities to smooth their investment decisions.(See Hallward-Driemeier, (2000)).

One issue in using the production data over time is the use of an appropriate deflator. With variations in the extent of price changes across sectors and between domestic and foreign prices, aggregate deflators can be misleading. Thus, firm-specific price changes are reported, see Table 4. Given the extent of the devaluation that occurred during the time of the survey, it is particularly important to distinguish between domestic and foreign price changes. Firms were asked to report the average change in the prices of four categories of goods. The first two are of inputs, those inputs from domestic sources and those that are imported. The last two reflect changes in prices of sales, for goods sold domestically and for goods that are exported. These prices changes, in conjunction with the accompanying weights for the shares of inputs that are imported or purchased from domestic sources and of goods sold abroad and domestically, firmspecific deflators can be constructed. It should be noted that the responses represent indices for the establishment's entire product line, and do not reflect the changes in price of a single item. For researchers wanting a broader based price index, country-sector averages can be used. Looking at such an index reveals that there are significant sector differences in prices changes. Thus, autoparts experienced the most modest price increases; consistent with it being on of the hardest hit manufacturing sectors.

\section{Research Questions:}

- Are firms that use foreign-sourced technology or that have ISO-9000 certification producing higher value added per worker?

- What are the main correlates of high total factor productivity?

- How does economic and/or political uncertainty affect investment?

\section{Employment and Training}

Firms were asked to report total employment and employment by categories of workers. The classifications are: mangers and supervisors, engineers and technical workers, production workers and non-production workers. The exact definitions vary only slightly across countries so as to be consistent with the worker classifications reported to the departments of labor. Except for Korea, the categories also broken down by the share of male and female workers in each category. Information is also reported on the number of hirings, firings and vacancies. In addition, there is information on wages and total compensation. This is also reported by total employment and by worker categories.

This section contains questions on the training received by employees of the firms (see Figure 4). The number of workers in each category that received formal training is reported, along with the average number of weeks of training. Firms also indicate if training levels are higher or lower than they had been three years earlier. 
The share of workers with various levels of educational attainment are reported. At least four different levels are given that roughly correspond to primary education, secondary education, vocational training and tertiary education. The number and definitions of educational attainment to differ across countries reflecting the variations in education structures in each country.

Lastly, firms are asked to provide the share of labor costs in the total costs of production. This can provide a consistency check as total compensation and other components of costs and sales are reported elsewhere in the survey.

\section{Research Questions:}

- What influences a firm's decisions to invest in training its workers?

- What is the impact of labor regulations on hiring, growth, and technology decisions of firms?

- Are there gender differences in employment practices and if so, what are the factors shaping them?

\section{Corporate finance: assets, liabilities, collateral, guarantees}

This section provides detailed balance sheet information. It reports the assets and liabilities of the firms. It also asks for information on hedging, collateral and guarantees of loans. It also has certain entries for the income statement such as sales, cost of goods sold, profits, foreign exchange gains/losses and interest expenses. While much of this information is available for publicly traded companies, it is highly unusual to have it available for unlisted companies. This will allow for research to be extended to new classes of firms. However, precisely as this is information firms are not used to reporting, caveats regarding the quality of some of the entries should be kept in mind.

Short-term borrowing in foreign currency and the sudden reversal of capital flows are often cited as important causes of the financial crisis. Certainly average debt-equity ratios are high, particularly in Korea (see Table 6). And of these loans, the majority are short-term, leaving firms particularly vulnerable to large changes in interest rates (See Dwor-Frecaut, Hallward-Driemeier and Colaco (2000)). However, this data illustrates that for the manufacturing firms, foreign borrowing was concentrated in a small number of firms (See Kawai, Hahm and Iarossi (2000)). Based on the survey results, the manufacturing sector does not seem to have been a major player, particularly relative to the real estate and financial services sectors. With the exception of Korea, less than $10 \%$ of financing was in foreign currency, see Figure 9. Korea is notable for its greater reliance on foreign borrowing, with a quarter of firms engaging in this practice. That there are more listed companies in the Korean sample is one explanation for this. Of the share of financing that is in foreign currency, only in Korea and Malaysia is the majority of it not short-term. However, it remains true that most of the effect of the depreciation would have been transmitted through alternative channels (e.g. the impact on banks) than through the balance sheets of manufacturing firms.

\section{Research Questions}

- How does the indebtedness of firms affect performance?

- Can supplier credit substitute for financial institution debt?

- What factors affect the access to capital of similar firms in different countries? 


\section{Confldentiality}

Given the richness of the data and the confidential nature of some of the figures reported, modifications were made to protect the individual identities of firms. Safeguarding respondents' identities is in keeping with the legal requirements of the counterpart government agencies and ensured the cooperation of firm managers in responding to the survey and interviews. The process by which the confidentiality of responses was protected was designed to minimize the loss of information to researchers.

Two sources of identifying information existed. The first was the firm name and contact information. All this information was simply deleted. The second source stems from the possibility of inferring the identity of the respondent based on combining a number of pieces of information in the survey. For example, if there is a textile plant with a foreign partner located in the northeast that has 1000 employees and has been in operation for 35 years, it would be easy to find it in the survey as there are not many firms who would fit such a description. Large firms are particularly susceptible to being identified and so the following three steps were taken:

i) Certain variables were aggregated into indicator variables. Thus, rather than give the province a firm was located in, firms are reported as being in the greater capital city area or outside this area. Likewise firms are reported as being founded pre and post 1990.

ii) Many variables were converted to ratios. Such a transformation rarely compromise the usefulness of the data to researchers, but makes it considerably more difficult to match up the data with prior information one might have on the levels of variables. Three denominators were used. For all variables regarding numbers of people, ratios are reported as a share of total employment (e.g. number of technical workers/total employment). For components of sales, income or expenditures, the ratios are shares of total sales. For components of assets, investment or liabilities, the ratios are reported over total assets. The ratios are calculated year by year, so that the denominator is of the same year as the numerator. The one exception are the values of employment, sales and assets for 1997 and 1998 are reported as ratios relative to their 1996 values.

iii) The value of the denominators (total employment, sales and assets in 1996) are available for small and medium enterprises, but are capped for large firms. Thus, for SMEs, the level values of all the variables can be calculated if they are of particular interest to the researcher. However, for the large firms, all the rest of the information is included in the database, but in ratio form rather than levels. Several criteria were used to define 'large' (i.e. over 500 employees, top $10 \%$ of sales, top 5\% of assets, top 5\% of paid up capital), and a firm is considered 'large' if it meets at least one criteria.

The database is available through the World Bank website, at: http:॥www.worldbank.orglresearchlfacs. The individual country databases and their corresponding documentation can be downloaded from this site. The documentation includes a more detailed description of the sampling methodology, the questionnaire, a file with variable definitions and names and any modification done to protect the confidentiality of the firms' responses. There is also a link to the site that gives a number of papers that have already been written using the data that were presented at a conference in Bangkok, attended by high ranking policy makers and members of the 
private sector. As new papers are written, it is hoped that they too will be made available on this site. Please contact the Research Department for information on how to do this.

\section{Conclusion:}

The database provides a rich source of information on a large number of firms. It has two primary areas of focus: one is the impact of the crisis and the other are longer run determinants of productivity, employment practices and financial structure. Quantitative, objective measures are provided so that indicators of firm performance can be

constructed. Already the data has been used for a regional conference attended by highranking policy makers. ${ }^{11}$ Government studies of the impact of the crisis and determinants of productivity are being currently being carried out. The discussion above has pointed out some of the many remaining avenues for additional research.

This database will be joined by additional country databases as part of the Firm Analysis and Competitiveness Surveys (FACS) initiative being spearheaded by the World Bank. The aim is to fill the gap in much needed micro-evidence using comparable instruments. This database is the first step in this important project.

\footnotetext{
${ }^{11}$ The conference was chaired by Dr. Il SaKong, former Minister of Finance of Korea and currently Chairman and CEO of the Institute for Global Economics; Dr. Zeti Akhtar Aziz, Deputy Governor of Bank Negara Malaysia, M.R. Chatu Mongol Sonakul, Governor of the Bank of Thailand; Secretary Benjamin Diokno, of the Department of Budget and Management of the Philippines and Dr. Mari Pangestru, Executive Director of htheCenter for Strategic and International Studies of Indonesia. The conference was held March 31-April 2, 1998 and provided 160 senior government officials, business people and academics to use the insights from the micro-date to discuss the prospects for Asian corporate recovery. The outcome of the discussions are available in "Asian Corporate Recovery: Findings from Firm-Level Surveys in Five Countries", Dominique Dwor-Frecaut, Francis Colaco and Mary Hallward-Driemeier (eds.), The World Bank, 2000.
} 


\section{Bibliography}

Aitken, Brian, Gordon Hanson and Ann Harrison. "Spillovers, Foreign Investment and Export Behavior." Journal of International Economics, 43(1/2) (August 1997), pp. 103-132.

Aitken, Brian and Ann Harrison. "Do Domestic Firms Benefit from Foreign Direct Investment? Evidence from Panel Data."

Arellano, M. and S. Bond, "Some Tests of Specification for Panel Data: Monte Carlo Evidence and an Application to Employment Equations," Review of Economic Studies 58, (1991) 277-297.

Athey, Michael and Prem Laumas, "Internal Funds and Corporate Investment in India" Journal of Development Economics 45 (1994), 287-303.

Biggs, Tyler, Manju Shah and Pradeep Srivastava. "Technological Capabilities and Learning in African Enterprises." World Bank Technical Paper No. 288, Africa Technical Department Series, 1995.

Biggs, Tyler and Pradeep Srivastava. "Structural Aspects of Manufacturing in SubSaharan Africa: Findings from a Seven Country Enterprise Survey. Wrld Bank Discussion Paper No. 346, 1996.

Brunetti, Aumo, Gregory Kisunko and Beatrice Weder. "Credibility of Rules and Economic Growth: Evidence from a Worldwide Survey of the Private Sector.” World Bank Economic Review v12, n3 (September 1998): 353-84.

Bigsten, Arne, Paul Collier, Stefan Dercon, Bernard Gauthier, Jan Willem Gunning, Anders Isaksson, Abena Oduro, Remco Oostendorp, Cathy Pattilo, Mans Soderbom, Michel Sylvain, Francis Teal and Albert Zeufack, "Investment in Africa's Manufacturing Sector: A Four Country Panel Data Analysis," Oxford Bulletin of Economics and Statistics, 61,4 (1999), 489-512.

Bond, Stephen, Julie Elston, Jacques Mairesse and Benoit Mulkay, "Financial Factors and Investment in Belgium, France, Germany and the U.K.: A Comparison Using Company Panel Data," NBER Working Paper Series No. 5900, (Jan. 1997)

Bond, Stephen and Costas Meghir, "Dynamic Investment Models and the Firm's Financial Policy, Review of Economic Studies (1994), 197-222.

Carpenter, Robert, Steven Fazzari and Bruce Petersen, "Financing Constraints and Inventory Investment: A Comparative Study with High-Frequency Panel Data," The Review of Economics and Statistics, (1998), 513-519. 
Claessens, Stijn and Simeon Djankov, "Publicly Listed East Asian Corporates: Growth, Financing and Risks" in Asian Corporate Recovery: Findings from Firm-Level Surveys in Five Countries, Washington DC: The World Bank (2000), p. 18-35.

Claessens, Stijn, Simeaon Djankov and Larry Lang, "Who Controls East Asian Corporates?", World Bank Policy Research Working Paper No. 2054. (1999).

Clerides, Sofronis, Saul Lach and James Tybout. "Is 'Learning-by-Exporting" Important? Micro-Dynamic Evidence from Colombia, Mexico and Morocco", Quarterly Journal of Economics, 454(3) (August 1998), pp. 903-947.

Dollar, David and Mary Hallward-Driemeier, "Crisis, Adjustment and Reform in Thailand's Industrial Firms, World Bank Research Observer, 15, 1 (2000) 1-22.

Dwor-Frecaut, Dominique, Mary Hallward-Driemeier and Francis Colaco, "Asian Corporate Credit Needs and Governance" in Asian Corporate Recovery: Findings from Firm-Level Surveys in Five Countries, Washington DC: The World Bank (2000), p. 61-81.

Dwor-Frecaut, Dominique, Francis Colaco, and Mary Hallward-Driemeier (eds.), Asian Corporate Recovery: Findings from Firm-Level Surveys in Five Countries, Washington DC: The World Bank (2000).

Fazzari, Steven, Glenn Hubbard and Bruce Peterson, "Financing Constraints and Corporate Investment," Brookings Papers on Economic Activity, (1988), 141-195.

Fazzari, Steven, Glenn Hubbard and Bruce Petersen, "Investment-cash flow sensitivities are useful: A comment on Kaplan and Zingales," The Quarterly Journal of Economics, (May 2000) 695-705.

Hallward-Driemeier, Mary, Dominique Dwor-Frecaut and Francis Colaco, "Asian Manufacturing Recovery: A Firm-Level Analysis" in Asian Corporate Recovery: Findings from Firm-Level Surveys in Five Countries, Washington DC: The World Bank (2000), p. 1-17.

Harris, John., Fabio Schiantarelli and Miranda Siregar, "The Effects of Financial Liberalization on the Capital Structure and Investment Decisions of Indonesian Manufacturing Establishments," The World Bank Economic Review (1994) 17-47.

Hoshi, Takeo, Anil Kashyap and David Scharfstein, "Corporate Structure, Liquidity and Investment: Evidence from Japanese Industrial Groups," The Quarterly Journal of Economics (February 1991), 33-60.

Hsieh, Chang-Tai, "Productivity Growth and Factor Prices in East Asia." American Economic Review 89(2), (1999), 133-138. 
Hubbard, R. Glenn, "Capital Market Imperfections and Investment," Journal of Economic Literature 35 (1998), 193-225.

Jorgenson, Dale, "Econometric Studies of Investment Behavior: A Survey," Journal of Economic Literature 9 (Dec. 1971), 1111-1147.

Kawai, Masahiro, Hongjoo Hahm and Giuseppe Iarossi, "Corporate Foreign Debt in East Asia: Too Much or Too Little?" in Asian Corporate Recovery: Findings from Firm-Level Surveys in Five Countries, Washington DC: The World Bank (2000), p. 111-121.

Kaplan, Steven N. and Luigi Zingales, "Do Investment-Cash Flow Sensitivities Provide Useful Measures of Financing Constraints?" The Quarterly Journal of Economics, (Feb. 1997) 47p.

Kaplan, Steven and Luigi Zingales, "Investment-Cash Flow Sensitivities are not Valid Measures of Financing Constraints," The Quarterly Journal of Economics, (May 2000) 707-712.

Kraay, Aart. "Exports and Economic Performance: Evidence from a Panel of Chinese Enterprises," The World Bank Policy Research Working Paper.

Krugman, Paul. "The Myth of Asia's Miracle" Foreign Affairs, 73 (6) 1994, p. 62-78.

Levine, Ross. "Financial Development and Economic Growth: Views and Agenda," Journal of Economic Literature, 35(2), (June 1997), p.688-726.

Little, Ian. "Small Manufacturing Enterprises in Developing Countries," World Bank Economic Review, Jan. 1987 1(2), p. 203-236.

Little, Ian, Dipak Mazumdar and John Page, Small Manufacturing Enterprises: A Comparative Analysis of India and Other Economies. New York: Oxford University Press, 1987.

Mairesse, Jacques, Bronwyn Hall and Benoit Mulkay, "Firm-Level Investment in France and the United States: An Exploration of What We Have Learned in Twenty Years," NBER Working Paper No. 7435.

Mairesse, J. and B. Dormont. "Labour and Investment Demand at the Firm Level: A Comparison of French, German and U.S. Manufacturing 1970-79," European Economic Review, 28(2) (1985) 201-231.

Meng, Xin and Ronald Duncan, "Corporate Employment and Public Policy" in Asian Corporate Recovery: Findings from Firm-Level Surveys in Five Countries, Washington DC: The World Bank (2000), p.123-140. 
Nabi, Ijaz, "Investment in Segmented Capital Markets," The Quarterly Journal of Economics (1989) 453-462.

Recanatini, Francesca, Scott Wallsten and Colin Xu, "Surveying Surveys and Questioning Questions," World Bank Policy Research Working Paper, No. 2307 (March 2000).

Reinikka, Ritva and Jakob Svensson, "Confronting Competition: Investment Response and Constraints in Uganda," World Bank mimeo (1999).

Roberts, Mark and James Tybout. Industrial Evolution in Developing Countries: Micro Patterns of Turnover, Productivity and Market Structure. New York: Oxford University Press, 1996.

Rodrik, Dani. "TFPG Controversies, Institutions and Economic Performance in East Asia." NBER Working Paper No. 5914, (February 1997).

Schaller, Hunter, "Asymmetric Information, Liquidity Constraints and Canadian Investment," Canadian Journal of Economics 26 (August 1993), 552-574.

Stiglitz, Joseph and Andrew Weiss, "Credit Rationing in Markets with Imperfect Information," The American Economic Review 71, 3 (1981) 393-410.

Stone, Andrew, "Listening to Firms," The World Bank Policy Research Working Paper, No. 923 (1992).

Tan, Hong W. and Geeta Batra, Enterprise Training in Developing Countries: Incidence, Productivity Effects and Policy Implications, The World Bank, 1995.

Tybout, James R, "Credit Rationing and Investment Behavior in a Developing Country," Review of Economics and Statistics 65 (1983), 598-607.

Tybout, James, "Manufacturing Firms in Developing Countries: How Well do they do and Why?," The World Bank Policy Research Working Paper, No. 1965 (1998).

Recanatini, Francesca, Scott Wallsten and Lixin Colin Xu, "Surveying Surveys and Questioning Questions: Learning from the World Bank Experience" World Bank Policy Research Working Paper, No. 2307 (2000).

Waiquamdee, Atchana, Soravis Drairiksh, and Wasana Phongsanarakul, "Corporates' Views of the Constraints to Recovery" in Asian Corporate Recovery: Findings from Firm-Level Surveys in Five Countries, Washington DC: The World Bank (2000), p. 18-35.

Whited, Toni M., "Debt, Liquidity Constraints, and Corporate Investment: Evidence from Panel Data," Journal of Finance 47 (Sept. 1992), 1425-1460. 
World Bank, The East Asian Miracle, Washington D.C. 1993.

Young, Alwyn, "The Tyranny of Numbers: Confronting the Statistical Realities of the East Asian Growth Experience." Quarterly Journal of Economics, 110 (1995) 641-680.

Young, Alwyn. "A Tale of Two Cities: Factor Accumulation and Technical Change in Hong Kong and Singapore." NBER Macroeconomics Annual, 1992. 
Table 1. Characteristics of the Sample

\begin{tabular}{|c|c|c|c|c|c|c|c|c|c|c|c|c|}
\hline & \multicolumn{2}{|c|}{ Size } & \multicolumn{2}{|c|}{ Expont orientation } & \multicolumn{2}{|c|}{ FDI fim } & \multicolumn{5}{|c|}{ Sector } & \multirow{2}{*}{$\begin{array}{c}\text { Total } \\
\text { \# of firms }\end{array}$} \\
\hline & Small & Large & Nonexporters & Exporters & No & Yes & Food & Textile/gament & Electr./Mach. & Chem. & Auto. & \\
\hline \multicolumn{13}{|l|}{ Country } \\
\hline Indonesia & $53 \%$ & $47 \%$ & $61 \%$ & $39 \%$ & $84 \%$ & $16 \%$ & $32 \%$ & $26 \%$ & $13 \%$ & $29 \%$ & $0 \%$ & 940 \\
\hline Korea, Rep. of & $65 \%$ & $35 \%$ & $25 \%$ & $75 \%$ & $83 \%$ & $17 \%$ & $0 \%$ & $23 \%$ & $35 \%$ & $28 \%$ & $14 \%$ & 857 \\
\hline Malaysia & $73 \%$ & $27 \%$ & $53 \%$ & $47 \%$ & $74 \%$ & $26 \%$ & $22 \%$ & $26 \%$ & $17 \%$ & $17 \%$ & $4 \%$ & 849 \\
\hline Philippines & $47 \%$ & $53 \%$ & $47 \%$ & $53 \%$ & $65 \%$ & $35 \%$ & $24 \%$ & $38 \%$ & $20 \%$ & $17 \%$ & $0 \%$ & 694 \\
\hline Thailand & $62 \%$ & $38 \%$ & $43 \%$ & $57 \%$ & $70 \%$ & $30 \%$ & $10 \%$ & $54 \%$ & $16 \%$ & $0 \%$ & $20 \%$ & 652 \\
\hline \multicolumn{13}{|l|}{ Sector } \\
\hline Food & $64 \%$ & $36 \%$ & $63 \%$ & $37 \%$ & $84 \%$ & $16 \%$ & .. & .. &.. & .. & .. & 718 \\
\hline Textiles and garments & $61 \%$ & $39 \%$ & $47 \%$ & $53 \%$ & $82 \%$ & $18 \%$ & .. & .. & .. & .. & .. & 1291 \\
\hline Electronics and electrical machinery & $56 \%$ & $44 \%$ & $30 \%$ & $70 \%$ & $60 \%$ & $40 \%$ & .. & .. & .. & .. & .. & 806 \\
\hline Chemicals & $60 \%$ & $40 \%$ & $46 \%$ & $54 \%$ & $76 \%$ & $24 \%$ & .. & .. & .. & .. & .. & 779 \\
\hline Auto parts & $63 \%$ & $37 \%$ & $45 \%$ & $55 \%$ & $74 \%$ & $26 \%$ & .. & .. & .. & .. & .. & 276 \\
\hline \multicolumn{13}{|l|}{ Size } \\
\hline Small & .. & .. & $61 \%$ & $39 \%$ & $86 \%$ & $14 \%$ & $18 \%$ & $32 \%$ & $18 \%$ & $20 \%$ & $8 \%$ & 2186 \\
\hline Large & .. & .. & $24 \%$ & $76 \%$ & $62 \%$ & $38 \%$ & $16 \%$ & $32 \%$ & $23 \%$ & $20 \%$ & $.7 \%$ & 1404 \\
\hline \multicolumn{13}{|l|}{ Export orientation } \\
\hline Nonexporters & $80 \%$ & $20 \%$ & .. & .. & $92 \%$ & $8 \%$ & $25 \%$ & $33 \%$ & $13 \%$ & $19 \%$ & $7 \%$ & 1785 \\
\hline Exporters & $44 \%$ & $56 \%$ & .. & .. & $63 \%$ & $37 \%$ & $12 \%$ & $32 \%$ & $26 \%$ & $19 \%$ & $7 \%$ & 2084 \\
\hline \multicolumn{13}{|l|}{ FDI fims } \\
\hline No & $69 \%$ & $31 \%$ & $54 \%$ & $46 \%$ & .. & .. & $20 \%$ & $35 \%$ & $17 \%$ & $20 \%$ & $7 \%$ & 2985 \\
\hline Yes & $38 \%$ & $62 \%$ & $19 \%$ & $81 \%$ & .. & .. & $12 \%$ & $25 \%$ & $34 \%$ & $20 \%$ & $7 \%$ & 945 \\
\hline \multicolumn{13}{|l|}{ Indebtedness } \\
\hline Low & $63 \%$ & $37 \%$ & $49 \%$ & $51 \%$ & $73 \%$ & $27 \%$ & $17 \%$ & $33 \%$ & $22 \%$ & $20 \%$ & $8 \%$ & \\
\hline High & $55 \%$ & $45 \%$ & $36 \%$ & $64 \%$ & $76 \%$ & $24 \%$ & $12 \%$ & $35 \%$ & $24 \%$ & $19 \%$ & $9 \%$ & \\
\hline \multicolumn{13}{|l|}{ Foreign borrowing } \\
\hline No & $67 \%$ & $33 \%$ & $49 \%$ & $51 \%$ & $80 \%$ & $20 \%$ & $16 \%$ & $36 \%$ & $21 \%$ & $20 \%$ & $8 \%$ & 1656 \\
\hline Yes & $37 \%$ & $63 \%$ & $13 \%$ & $87 \%$ & $58 \%$ & $42 \%$ & $6 \%$ & $29 \%$ & $30 \%$ & $21 \%$ & $13 \%$ & 907 \\
\hline Total & $61 \%$ & $39 \%$ & $46 \%$ & $54 \%$ & $76 \%$ & $24 \%$ & $18 \%$ & $32 \%$ & $20 \%$ & $20 \%$ & $7 \%$ & 3992 \\
\hline
\end{tabular}

Note: Percentages represent the share of the row variable that has the corresponding column characteristic.

Source: World Bank, Asian Corporate Crisis and Pecovery Firm-Level Survey 1999 
Table 2. Who Is Recovering: Characteristics of the Firms that Expanded in 1998 Relative to the End of 1997 Reported as percent (by country) of firms that have expanded

\begin{tabular}{|c|c|c|c|c|c|c|c|c|c|c|c|c|c|}
\hline \multirow{3}{*}{$\begin{array}{r}\text { Indonesia } \\
\text { Korea }\end{array}$} & \multicolumn{2}{|c|}{ By size } & \multicolumn{2}{|c|}{ By export orientation } & \multicolumn{2}{|c|}{ FDI firm } & \multicolumn{5}{|c|}{ Sector } & \multirow[b]{2}{*}{$\begin{array}{c}\text { Total } \\
51\end{array}$} & \multirow[b]{2}{*}{$\begin{array}{c}\% \text { Sample } \\
6.3 \%\end{array}$} \\
\hline & $\begin{array}{l}\text { Small } \\
43.1 \%\end{array}$ & $\begin{array}{l}\text { Large } \\
56.9 \%\end{array}$ & $\begin{array}{c}\text { Nonexporters } \\
40.1 \%\end{array}$ & $\begin{array}{c}\text { Exporters } \\
59.6 \%\end{array}$ & $\begin{array}{c}\text { No } \\
79.4 \%\end{array}$ & $\begin{array}{c}\text { Yes } \\
20.6 \%\end{array}$ & $\begin{array}{l}\text { Food } \\
47.6 \%\end{array}$ & $\begin{array}{l}\text { Text. and garm. } \\
7.9 \%\end{array}$ & $\begin{array}{c}\text { Elec. mach. } \\
17.5 \%\end{array}$ & $\begin{array}{l}\text { Chem. } \\
26.9 \%\end{array}$ & Auto. & & \\
\hline & $70.1 \%$ & $29.1 \%$ & $21.9 \%$ & $78.1 \%$ & $81.9 \%$ & $18.1 \%$ & & $31.4 \%$ & $25.0 \%$ & $32.4 \%$ & $1.0 \%$ & 103 & $12.0 \%$ \\
\hline Malaysia & $65.1 \%$ & $34.9 \%$ & $39.3 \%$ & $60.7 \%$ & $68.5 \%$ & $31.5 \%$ & $31.5 \%$ & $19.1 \%$ & $20.2 \%$ & $27.0 \%$ & $2.3 \%$ & 86 & $10.6 \%$ \\
\hline Philippines & $43.9 \%$ & $56.3 \%$ & $33.8 \%$ & $66.2 \%$ & $59.8 \%$ & $40.2 \%$ & $25.6 \%$ & $40.2 \%$ & $19.5 \%$ & $14.1 \%$ & & 71 & $12.6 \%$ \\
\hline Thailand & $56.0 \%$ & $44.0 \%$ & $25.9 \%$ & $74.1 \%$ & $67.0 \%$ & $33.0 \%$ & $12.1 \%$ & $66.4 \%$ & $12.9 \%$ & & $8.6 \%$ & 100 & $15.2 \%$ \\
\hline Total & $57.9 \%$ & $42.1 \%$ & $30.8 \%$ & $69.2 \%$ & $71.2 \%$ & $28.8 \%$ & $20.4 \%$ & $36.3 \%$ & $21.3 \%$ & $19.1 \%$ & $2.9 \%$ & & \\
\hline
\end{tabular}

Source: World Bank, Asian Corporate Crisis and Recovery Firm-Level Survey 1999 
Table 3. Source of Liquidity Problem

\begin{tabular}{|c|c|c|c|c|c|c|c|}
\hline & \multirow{2}{*}{$\begin{array}{c}\begin{array}{c}\text { Share claiming inadequate } \\
\text { liquidity }\end{array} \\
\text { Yes } \\
\end{array}$} & \multicolumn{6}{|c|}{ By source of problem } \\
\hline & & Lower revenue & High input costs & Debt burden & Insuff. wk. cap. & Insuff. sup. crd. & Others \\
\hline \multicolumn{8}{|l|}{ Country } \\
\hline Indonesia & $35 \%$ & 3.5 & 3.7 & n.a. & 2.9 & 2.5 & 1.8 \\
\hline Korea & $48 \%$ & 4.1 & 3.4 & 3.1 & 3.2 & 2.5 & 2.5 \\
\hline Malaysia & $25 \%$ & 4.1 & 4.0 & 3.3 & 3.3 & 2.9 & 1.8 \\
\hline Philippines & $23 \%$ & 3.8 & n.a. & n.a. & 3.3 & 2.8 & 2.3 \\
\hline Thailand & $56 \%$ & 4.4 & 4.3 & 3.9 & 3.7 & 3.2 & 4.2 \\
\hline \multicolumn{8}{|l|}{ Sector } \\
\hline Food & $28 \%$ & 3.7 & 3.7 & 3.3 & 3.0 & 2.5 & 2.0 \\
\hline Textiles and garments & $42 \%$ & 4.0 & 4.0 & 3.5 & 3.4 & 2.9 & 2.4 \\
\hline Electron. and electrical mach. & $37 \%$ & 4.3 & 3.7 & 3.2 & 3.3 & 2.7 & 2.0 \\
\hline Chemicals & $33 \%$ & 3.8 & 3.7 & 3.3 & 3.1 & 2.6 & 2.0 \\
\hline Auto parts & $61 \%$ & 4.6 & 3.9 & 3.6 & 3.5 & 2.8 & 3.0 \\
\hline \multicolumn{8}{|l|}{ Size } \\
\hline Small & $42 \%$ & 4.2 & 3.8 & 3.3 & 3.2 & 2.7 & 2.1 \\
\hline Large & $32 \%$ & 3.8 & 3.8 & 3.7 & 3.4 & 2.8 & 2.3 \\
\hline \multicolumn{8}{|l|}{ Export orientation } \\
\hline Nonexporters & $41 \%$ & 4.1 & 3.9 & 3.4 & 3.2 & 2.6 & 1.9 \\
\hline Exporters & $36 \%$ & 4.0 & 3.8 & 3.5 & 3.4 & 2.9 & 2.5 \\
\hline \multicolumn{8}{|l|}{ FDI firms } \\
\hline No & $41 \%$ & 4.1 & 3.8 & 3.4 & 3.3 & 2.7 & 2.1 \\
\hline Yes & $30 \%$ & 4.0 & 4.0 & 3.6 & 3.2 & 2.7 & 2.4 \\
\hline \multicolumn{8}{|l|}{ Indebtedness } \\
\hline Low & $34 \%$ & 4.1 & 4.0 & 3.4 & 3.3 & 2.7 & 1.9 \\
\hline High & $44 \%$ & 4.2 & 3.9 & 3.5 & 3.5 & 3.0 & 2.5 \\
\hline \multicolumn{8}{|l|}{ Foreign borrowing } \\
\hline No & $40 \%$ & 4.2 & 3.9 & 3.4 & 3.4 & 2.9 & 3.1 \\
\hline Yes & $40 \%$ & 4.0 & 3.7 & 3.6 & 3.4 & 2.6 & 2.7 \\
\hline Total & $38 \%$ & 4.1 & 3.8 & 3.4 & 3.3 & 2.7 & 2.2 \\
\hline
\end{tabular}

Source: World Bank, Asian Corporate Crisis and Recovery Firm-Level Survey 1999 
TABLE 4: FIRM-SPECIFIC PRICE DEFLATORS: SALES (1996==100)

\begin{tabular}{|c|c|c|c|c|c|c|c|c|}
\hline & & Food & Textiles & Garments & Chemical & Machinery & Electronics & Autoparts \\
\hline \multirow[t]{2}{*}{ Indonesia } & 1997 & 141 & 140 & 145 & 144 & & 142 & \\
\hline & 1998 & 192 & 203 & 211 & 217 & & 213 & \\
\hline \multirow[t]{2}{*}{ Korea } & 1997 & & 109 & & 107 & 109 & 103 & 105 \\
\hline & 1998 & & 116 & & 122 & 115 & 107 & 112 \\
\hline \multirow[t]{2}{*}{ Malaysia } & 1997 & 120 & 122 & 120 & 115 & 126 & 116 & 110 \\
\hline & 1998 & 133 & 136 & 134 & 127 & 139 & 127 & 118 \\
\hline \multirow[t]{2}{*}{ Philippines } & 1997 & 115 & 122 & 127 & 130 & & 129 & \\
\hline & 1998 & 126 & 140 & 142 & 148 & & 151 & \\
\hline \multirow[t]{2}{*}{ Thailand } & 1997 & 115 & 117 & 114 & & & 119 & 114 \\
\hline & 1998 & 122 & 129 & 126 & & & 131 & 125 \\
\hline
\end{tabular}

PRICE DEFLATORS: INPUT PRICES (1996=100)

\begin{tabular}{|c|c|c|c|c|c|c|c|c|}
\hline & & Food & Textiles & Garments & Chemical & Machinery & Electronics & Autoparts \\
\hline \multirow[t]{2}{*}{ Indonesia } & 1997 & 150 & 148 & 152 & 147 & & 146 & \\
\hline & 1998 & 237 & 245 & 237 & 236 & & 221 & \\
\hline \multirow[t]{2}{*}{ Korea } & 1997 & & 108 & & 110 & 110 & 107 & 105 \\
\hline & 1998 & & 121 & & 128 & 124 & 117 & 115 \\
\hline \multirow[t]{2}{*}{ Malaysia } & 1997 & 119 & 121 & 123 & 120 & 122 & 121 & 113 \\
\hline & 1998 & 134 & 140 & 137 & 134 & 141 & 138 & 124 \\
\hline \multirow[t]{2}{*}{ Philippines } & 1997 & 115 & 120 & 126 & 130 & & 130 & \\
\hline & 1998 & 126 & 132 & 145 & 148 & & 146 & \\
\hline \multirow[t]{2}{*}{ Thailand } & 1997 & 124 & 123 & 122 & & & 126 & 125 \\
\hline & 1998 & 143 & 139 & 137 & & & 149 & 138. \\
\hline
\end{tabular}


TABLE 5: CAPITAL PER WORKER, 1997

\begin{tabular}{lccccc}
\hline \hline & Indonesia & Korea & Malaysia & Philippines & Thailand \\
\cline { 2 - 6 } Food & 1.49 & & 5.71 & 3.92 & 4.83 \\
Textile & 2.11 & 11.85 & 8.28 & 3.04 & 4.86 \\
Garment & 0.79 & & 1.31 & 1.29 & 0.64 \\
Chemicals & 2.58 & 18.83 & 12.34 & 4.91 & \\
Machinery & & 10.15 & 5.88 & & \\
Electronics & 2.61 & 12.08 & 7.96 & 3.22 & 4.49 \\
Autoparts & & 23.97 & 12.55 & & 5.65 \\
\hline
\end{tabular}


Table 6. Financial Structure by Firm Characteristics

\begin{tabular}{|c|c|c|c|c|c|c|c|c|c|}
\hline & \multicolumn{3}{|c|}{$\begin{array}{l}\text { Total equity } \\
\text { total financing }\end{array}$} & \multicolumn{3}{|c|}{$\begin{array}{c}\text { Short-term debt } / \\
\text { total debt }\end{array}$} & \multicolumn{3}{|c|}{$\begin{array}{c}\text { Foreign debt } \\
\text { total debt }\end{array}$} \\
\hline & 1996 & 1997 & 1998 & 1996 & 1997 & 1998 & 1996 & 1997 & 1998 \\
\hline \multicolumn{10}{|l|}{ Country } \\
\hline Indonesia & $52.7 \%$ & $53.7 \%$ & $56.3 \%$ & $55.4 \%$ & $55.1 \%$ & $56.2 \%$ & $6.9 \%$ & $6.0 \%$ & $6.1 \%$ \\
\hline Korea & $35.3 \%$ & $34.7 \%$ & $41.9 \%$ & $50.9 \%$ & $51.9 \%$ & $50.0 \%$ & $36.9 \%$ & $29.7 \%$ & $29.2 \%$ \\
\hline Malaysia & $44.6 \%$ & $46.2 \%$ & $45.5 \%$ & $52.5 \%$ & $53.1 \%$ & $52.8 \%$ & $8.5 \%$ & $9.8 \%$ & $10.0 \%$ \\
\hline Philippines & $37.6 \%$ & $43.9 \%$ & $44.3 \%$ & $51.3 \%$ & $55.8 \%$ & $55.5 \%$ & $8.7 \%$ & $8.9 \%$ & $8.8 \%$ \\
\hline Thailand & $47.1 \%$ & $46.8 \%$ & $51.1 \%$ & $55.3 \%$ & $57.6 \%$ & $56.8 \%$ & $10.7 \%$ & $12.4 \%$ & $13.2 \%$ \\
\hline \multicolumn{10}{|l|}{ Sector } \\
\hline Food & $48.7 \%$ & $50.5 \%$ & $51.3 \%$ & $53.6 \%$ & $54.2 \%$ & $53.9 \%$ & $5.7 \%$ & $5.6 \%$ & $5.0 \%$ \\
\hline Textiles and garments & $43.1 \%$ & $44.9 \%$ & $48.9 \%$ & $53.3 \%$ & $55.6 \%$ & $55.9 \%$ & $14.2 \%$ & $12.7 \%$ & $13.2 \%$ \\
\hline Electronics and electrical machinery & $40.4 \%$ & $41.7 \%$ & $44.5 \%$ & $53.8 \%$ & $55.5 \%$ & $54.9 \%$ & $23.1 \%$ & $21.9 \%$ & $21.3 \%$ \\
\hline Chemicals & $44.4 \%$ & $45.9 \%$ & $49.6 \%$ & $51.4 \%$ & $52.3 \%$ & $49.9 \%$ & $19.5 \%$ & $17.7 \%$ & $17.6 \%$ \\
\hline Auto parts & $42.0 \%$ & $43.2 \%$ & $46.6 \%$ & $52.4 \%$ & $53.3 \%$ & $52.5 \%$ & $26.4 \%$ & $22.1 \%$ & $23.5 \%$ \\
\hline \multicolumn{10}{|l|}{ Size } \\
\hline Small & $46.6 \%$ & $48.2 \%$ & $51.6 \%$ & $50.2 \%$ & $51.4 \%$ & $50.9 \%$ & $11.6 \%$ & $10.6 \%$ & $10.7 \%$ \\
\hline Large & $39.1 \%$ & $40.4 \%$ & $43.0 \%$ & $56.3 \%$ & $58.3 \%$ & $57.9 \%$ & $25.0 \%$ & $22.5 \%$ & $22.7 \%$ \\
\hline \multicolumn{10}{|l|}{ Export orientation } \\
\hline Nonexporters & $49.4 \%$ & $51.1 \%$ & $53.7 \%$ & $50.2 \%$ & $51.9 \%$ & $51.8 \%$ & $5.1 \%$ & $5.6 \%$ & $5.3 \%$ \\
\hline Exporters & $39.1 \%$ & $40.3 \%$ & $44.0 \%$ & $54.7 \%$ & $56.1 \%$ & $55.1 \%$ & $25.4 \%$ & $22.4 \%$ & $22.6 \%$ \\
\hline \multicolumn{10}{|l|}{ FDI firms } \\
\hline No & $43.8 \%$ & $45.3 \%$ & $48.5 \%$ & $50.9 \%$ & $52.4 \%$ & $51.6 \%$ & $14.1 \%$ & $11.9 \%$ & $12.0 \%$ \\
\hline Yes & $42.8 \%$ & $44.4 \%$ & $47.3 \%$ & $59.0 \%$ & $60.7 \%$ & $60.4 \%$ & $27.4 \%$ & $27.8 \%$ & $27.8 \%$ \\
\hline Total & $43.6 \%$ & $45.1 \%$ & $48.3 \%$ & $53.0 \%$ & $54.5 \%$ & $53.8 \%$ & $17.4 \%$ & $15.8 \%$ & $15.9 \%$ \\
\hline
\end{tabular}

Source: World Bank, Asian Corporate Crisis and Recovery Firm-Level Survey 1999 
Figure 1: Time to Clear Goods Through Customs

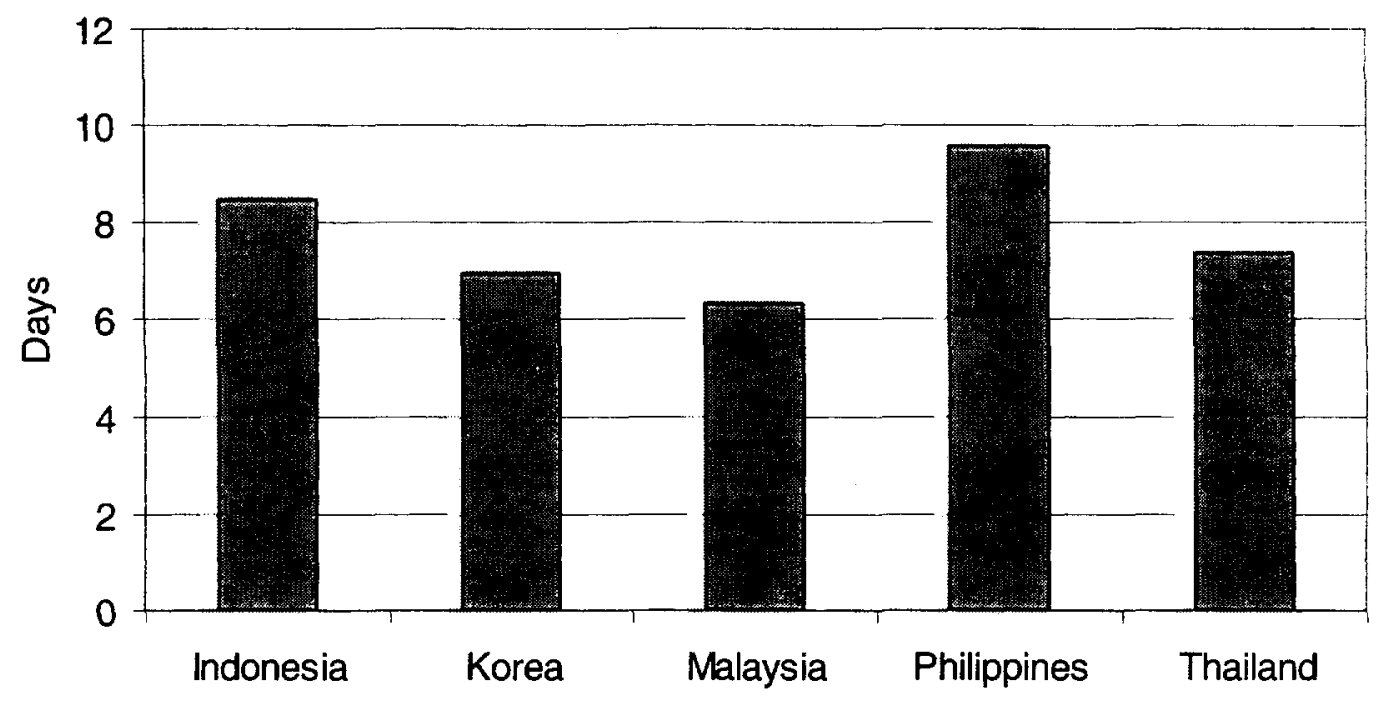


FIGURE 2: VINTAGE OF CAPITAL STOCKS

Non - Exporters

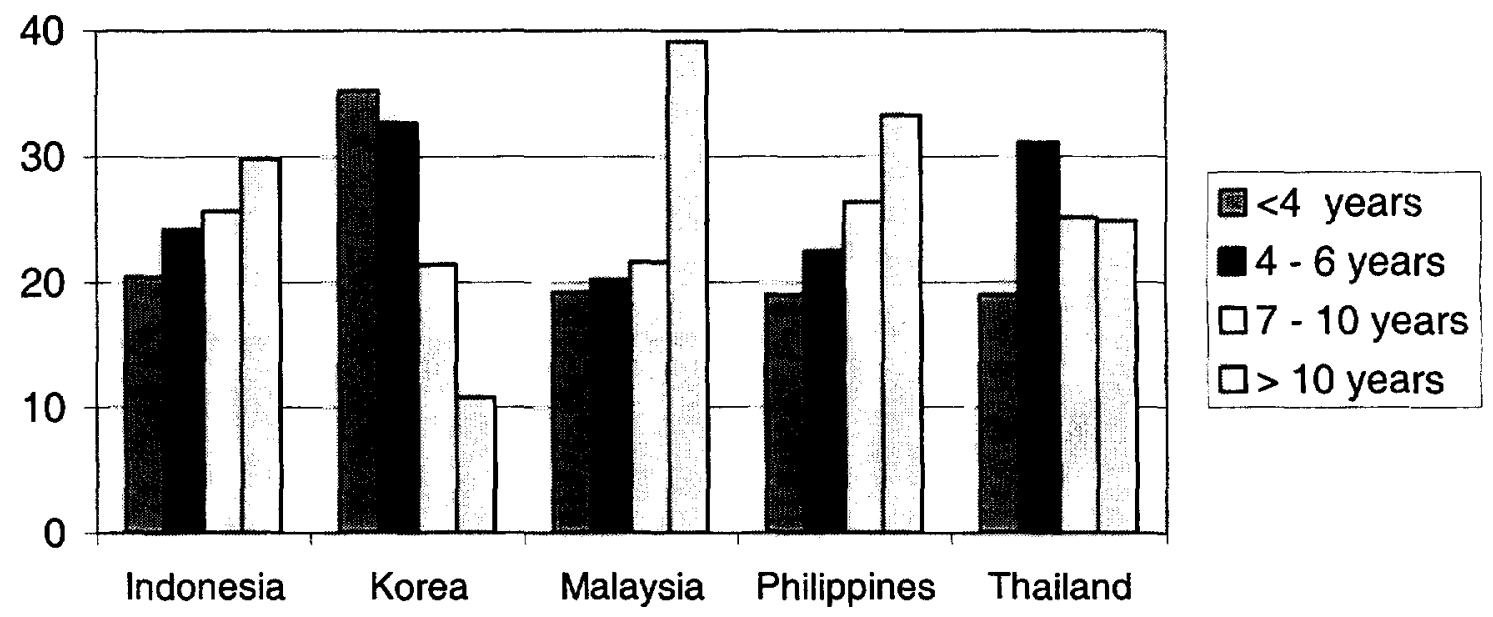

Exporters

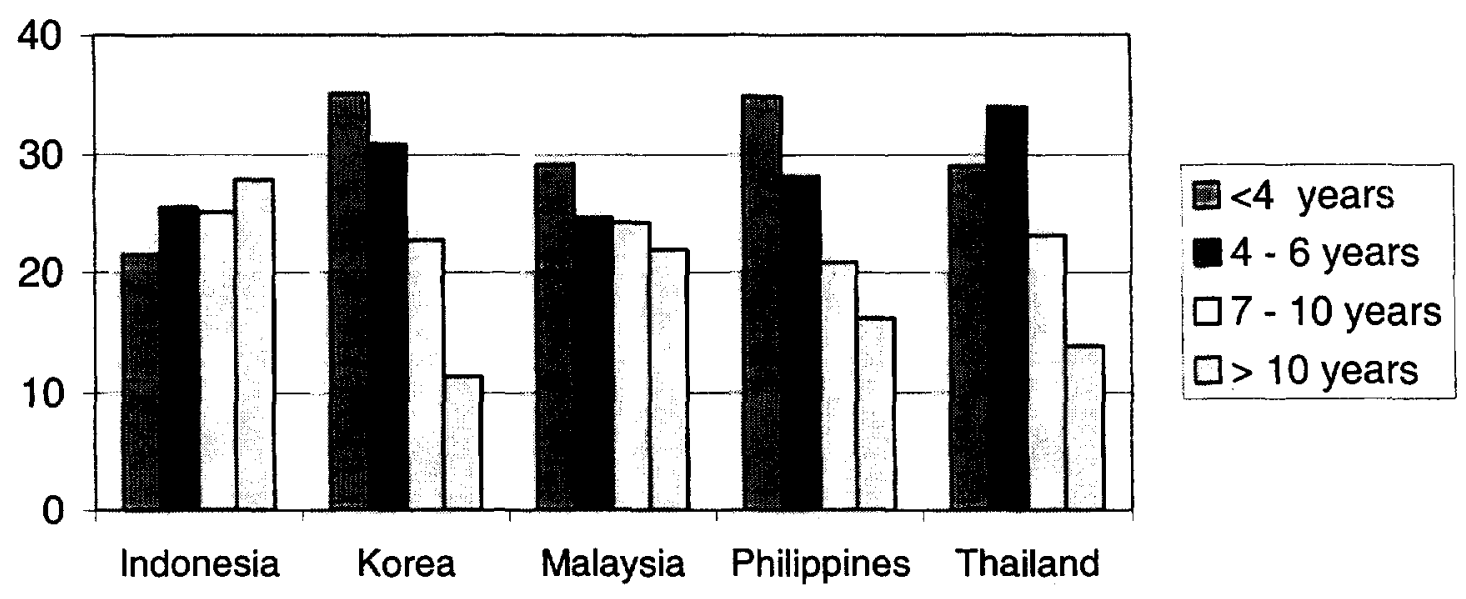


Figure 3. Sources of Working Capital, 1998
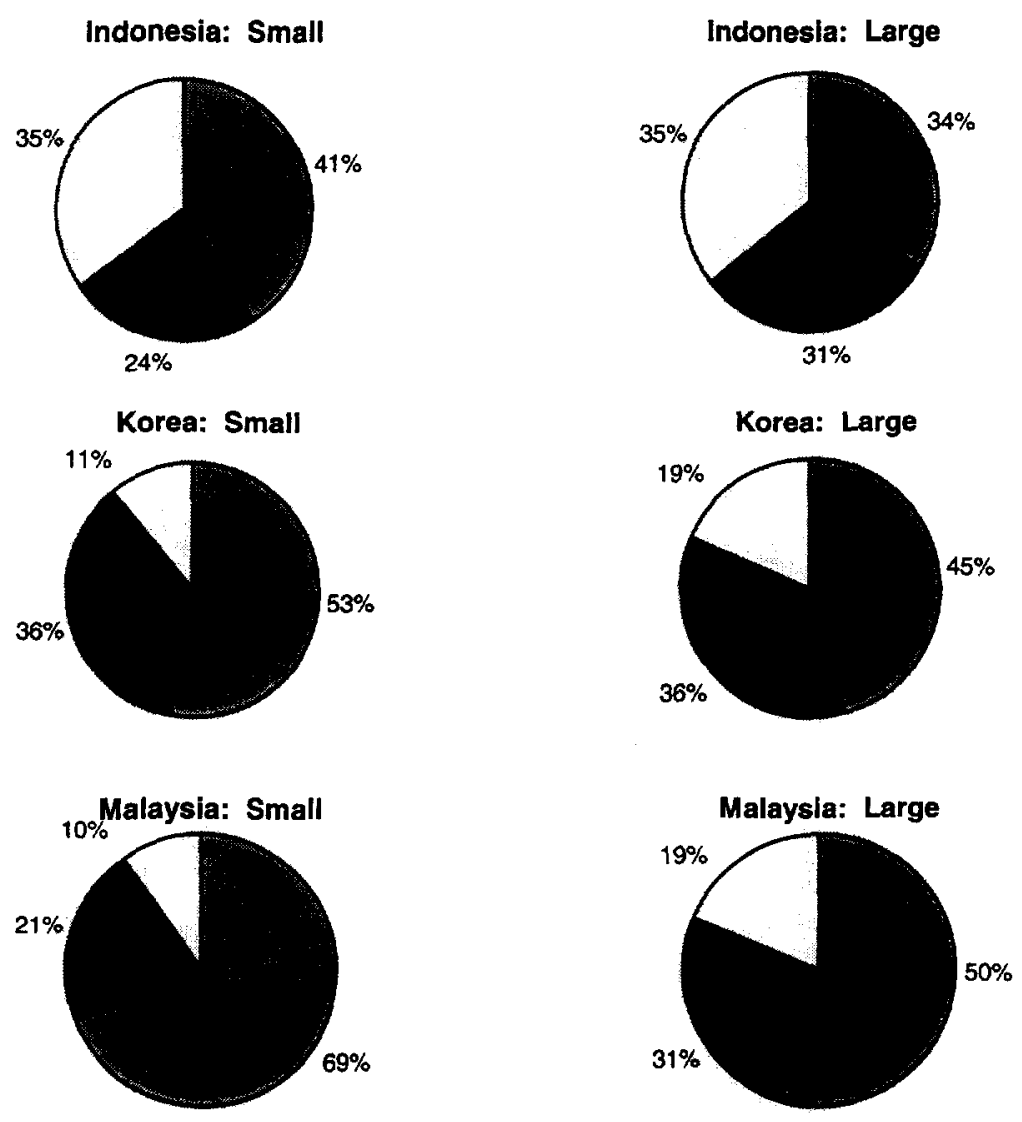

Philippines: Small

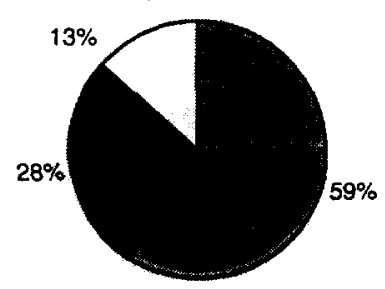

Phillppines: Large

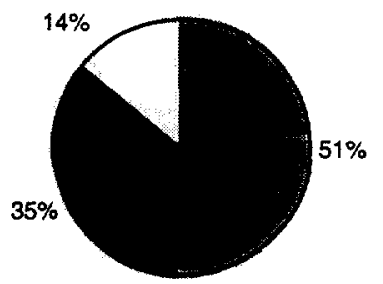

Thailand: Small

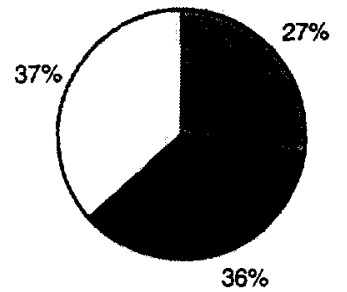

Thailand: Large

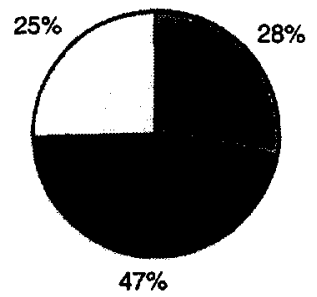

(⿴囗十) Retained earnings

Loans

Dother

Source: World Bank, Asian Corporate Crisis and Recovery Firm-Level Survey 1999 
Figure 4: Share of Firms with Formal Training Programs

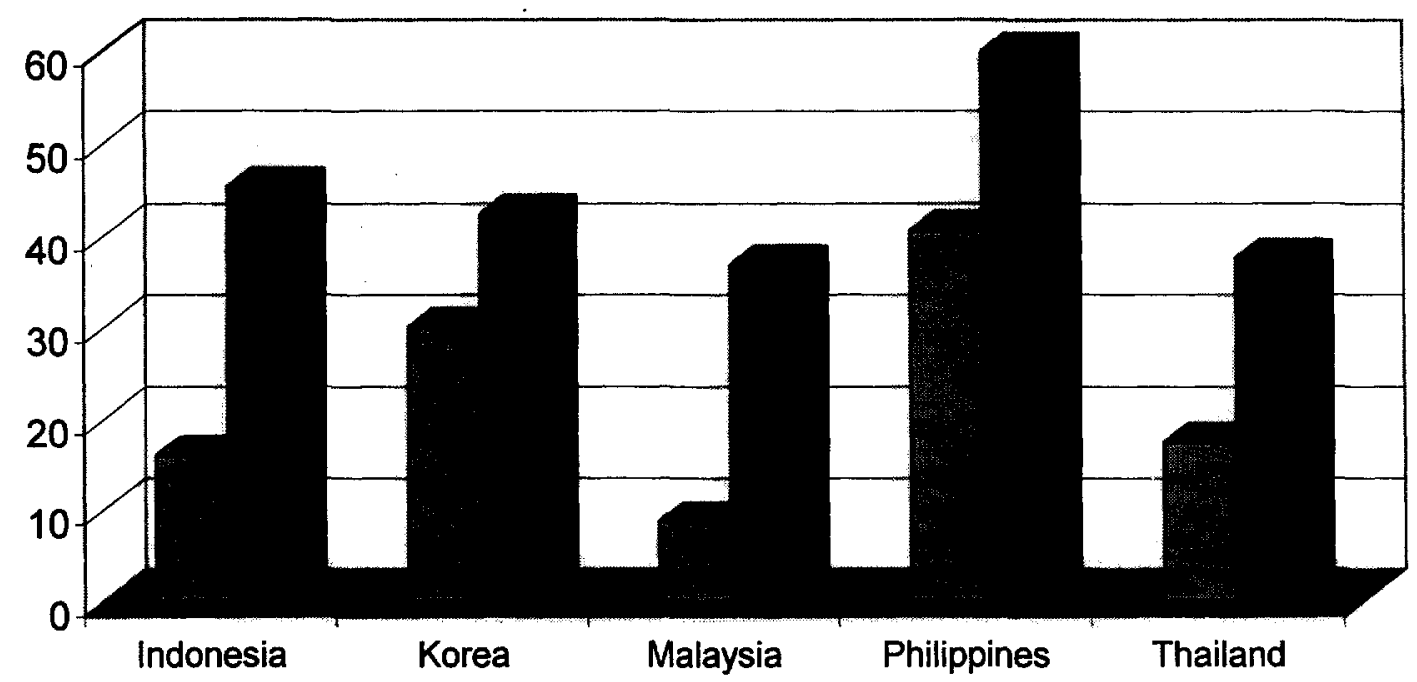

Non-Exporter Exporter 


\section{Figure 5. Foreign Debt as a Share of Total Debt}

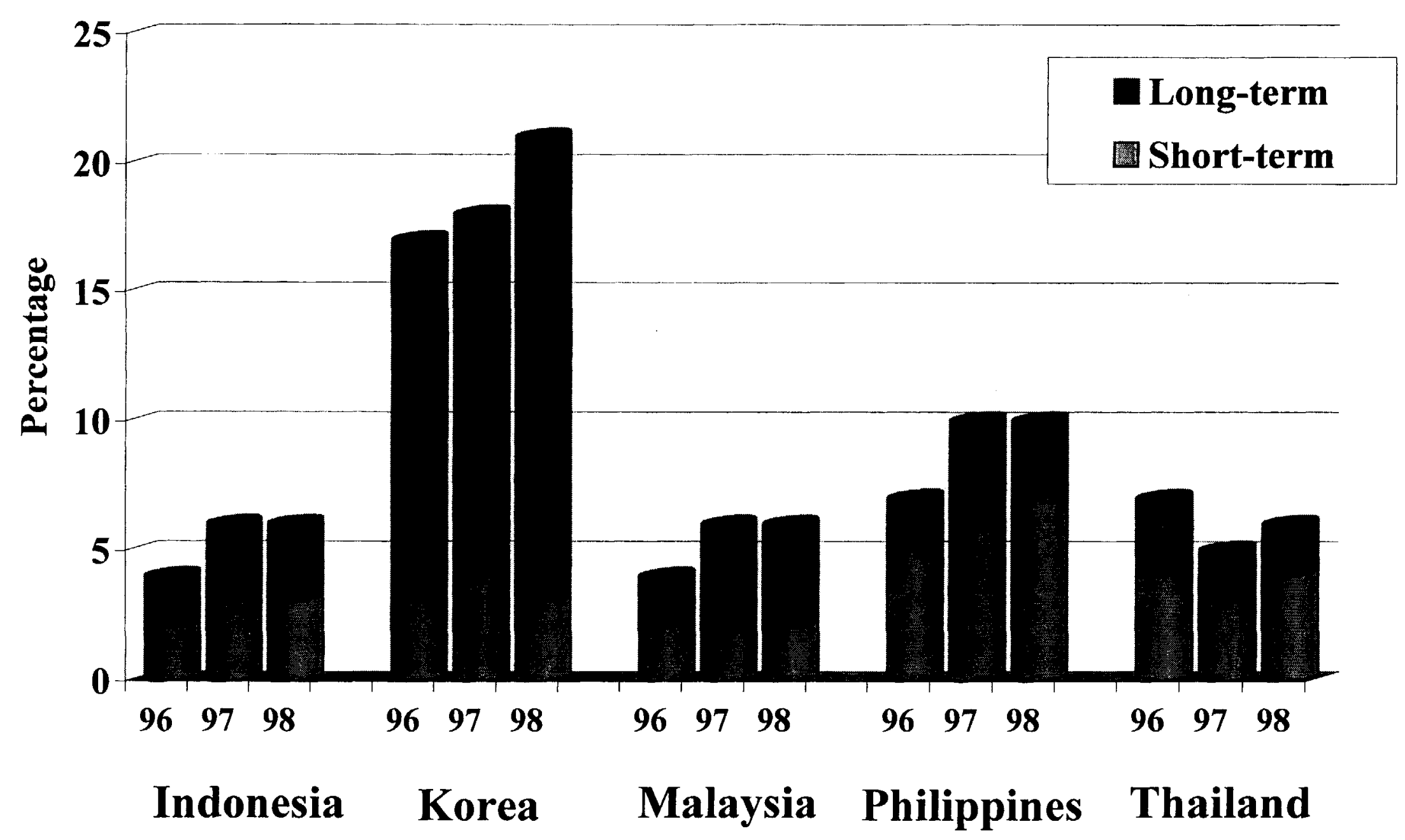




\section{Policy Research Working Paper Series}

Title

WPS2493 Annuity Markets in Comparative Perspective: Do Consumers Get Their Money's Worth?

WPS2494 The Relevance of Index Funds for Pension Investment in Equities

WPS2495 The Australian Annuity Market

WPS2496 Perspectives on the Sources of Heterogeneity in Indian Industry

WPS2497 State Policies and Women's Autonomy in China, India, and the Republic of Korea, 1950-2000: Lessons from Contrasting Experiences

WPS2498 Sustaining Economic Welfare: Estimating Changes in Per Capita Wealth

WPS2499 The Treatment of Non-Essential Inputs in a Cobb-Douglas Technology: An Application to Mexican Rural Household-Level Data

WPS2500 Investigating Corruption

WPS2501 Anti-Corruption Policies and Programs: A Framework for Evaluation

WPS2502 Implications of the Currency Crisis for Exchange Rate Arrangements in Emerging East Asia

WPS2503 Proposed Strategy for a Regional Exchange Rate Arrangement in Post-Crisis East Asia

WPS2504 Social Capital and the Quality of Government: Evidence from the United States
Author

Date

Contact

for paper

Estelle James

Dimitri Vittas

November 2000

A. Yaptenco 31823

Ajay Shah

Kshama Fernandes

David M. Knox

Somik V. Lall

G. Chris Rodrigo

Monica Das Gupta

Sunhwa Lee

Patricia Uberoi

Danning Wang

Lihong Wang

Xiaodan Zhang

Kirk Hamilton

Isidro Soloaga

Canice Prendergast

Jeff Huther

Anwar Shah

Masahiro Kawai

Shigeru Akiyama

Masahiro Kawai

Shinji Takagi

Stephen Knack
November 2000

November 2000

November 2000

November 2000

November 2000

December 2000

December 2000

December 2000

December 2000
A. Yaptenco 31823

A. Yaptenco 31823

R. Yazigi 37176

M. Das Gupta 31983

L. Rivera 82819

L. Tabada 36896

H. Sladovich 37698

A. Santos 31675

A. Azarcon 36049

A. Azarcon 36049

P. Sintim-Aboagye 38526 


\begin{tabular}{|c|c|c|c|c|}
\hline & Title & Author & Date & $\begin{array}{l}\text { Contact } \\
\text { for paper }\end{array}$ \\
\hline WPS2505 & Family Altruism and Incentives & Roberta Gatti & December 2000 & $\begin{array}{l}\text { R. Bonfield } \\
31248\end{array}$ \\
\hline WPS2506 & $\begin{array}{l}\text { Ethnicity and Wage Determination } \\
\text { in Ghana }\end{array}$ & $\begin{array}{l}\text { Abigail Barr } \\
\text { Abena Oduro }\end{array}$ & December 2000 & $\begin{array}{l}\text { R. Bonfield } \\
31248\end{array}$ \\
\hline WPS2507 & $\begin{array}{l}\text { Public Expenditures and } \\
\text { Environmental Protection: When Is } \\
\text { the Cost of Funds Irrelevant? }\end{array}$ & Gunnar S. Eskeland & December 2000 & $\begin{array}{l}\text { H. Sladovich } \\
37698\end{array}$ \\
\hline WPS2508 & $\begin{array}{l}\text { Sources of Financial Assistance for } \\
\text { Households Suffering an Adult } \\
\text { Death in Kagera, Tanzania }\end{array}$ & $\begin{array}{l}\text { Mattias Lundberg } \\
\text { Mead Over } \\
\text { Phare Mujinja }\end{array}$ & December 2000 & $\begin{array}{l}\text { V. Soukhanov } \\
35271\end{array}$ \\
\hline WPS2509 & $\begin{array}{l}\text { How Tax Policy and Incentives } \\
\text { Affect Foreign Direct Investment: } \\
\text { A Review }\end{array}$ & $\begin{array}{l}\text { Jacques Morisset } \\
\text { Neda Pirnia }\end{array}$ & December 2000 & $\begin{array}{l}\text { N. Busjeet } \\
33997\end{array}$ \\
\hline WPS2510 & $\begin{array}{l}\text { Environmental Protection and } \\
\text { Optimal Taxation }\end{array}$ & Gunnar S. Eskeland & December 2000 & $\begin{array}{l}\text { H. Sladovich } \\
37698\end{array}$ \\
\hline WPS2511 & $\begin{array}{l}\text { Monetary Policy under Flexible } \\
\text { Exchange Rates: An Introduction to } \\
\text { Inflation Targeting }\end{array}$ & Pierre-Richard Agénor & December 2000 & $\begin{array}{l}\text { M. Gosiengfiao } \\
33363\end{array}$ \\
\hline WPS2512 & $\begin{array}{l}\text { Quantifying the Impact of Technical } \\
\text { Barriers to Trade: A Framework for } \\
\text { Analysis }\end{array}$ & $\begin{array}{l}\text { Keith E. Maskus } \\
\text { John S. Wilson } \\
\text { Tsunehiro Otsuki }\end{array}$ & December 2000 & $\begin{array}{l}\text { L. Tabada } \\
36896\end{array}$ \\
\hline WPS2513 & $\begin{array}{l}\text { Do State Holding Companies Facilitate } \\
\text { Private Participation in the Water Sectc } \\
\text { Evidence from Côte d'Ivoire, the Gamb } \\
\text { Guinea, and Senegal }\end{array}$ & $\begin{array}{l}\text { Michel Kerf } \\
\text { or? } \\
\text { jia, }\end{array}$ & December 2000 & $\begin{array}{l}\text { M. Leon } \\
36151\end{array}$ \\
\hline WPS2514 & $\begin{array}{l}\text { Intersectoral Dynamics and Economic } \\
\text { Growth in Ecuador }\end{array}$ & $\begin{array}{l}\text { Norbert M. Fiess } \\
\text { Dorte Verner }\end{array}$ & January 2001 & $\begin{array}{l}\text { A. Pillay } \\
88046\end{array}$ \\
\hline
\end{tabular}

